\title{
PEMANFAATAN DAUN KEMANGI (Ocinum sanctum) SEBAGAI PRODUK ANTISEPTIK UNTUK PREVENTIF PENYAKIT DI DESA BATUJAI KABUPATEN LOMBOK TENGAH
}

\author{
Abdul Rahman Wahid"1), Dzun Haryadi Ittiqo'), Nurul Qiyaam¹), Melati Permata Hati1), \\ Yuli Fitriana ${ }^{1)}$, Anjeli Amalia ${ }^{1)}$, Atis Anggraini ${ }^{1)}$ \\ 1)Program Studi Diploma Farmasi, Fakultas Ilmu Kesehatan, Universitas Muhammadiyah Mataram, Mataram, NTB, Indonesia \\ Corresponding author: Abdul Rahman Wahid \\ E-mail : rahman_apt@yahoo.co.id
}

Diterima 01 September 2020, Direvisi 19 Oktober 2020, Disetujui 19 Oktober 2020

\begin{abstract}
ABSTRAK
Tangan merupakan anggota badan yang sering terkontaminasi oleh mikroba. Salah satu cara untuk menghilangkan mikroba di tangan yaitu dengan mencuci tangan menggunakan sabun. Selain menggunakan sabun, mencuci tangan dapat juga menggunakan handsanitizer. Salah satu tanaman yang dapat digunakan sebagai bahan handsanitizer adalah daun kemangi. Ekstrak daun kemangi mengandung senyawa yang berperan sebagai antibakteri yaitu tanin, flavonoid dan minyak atsiri. Kegiatan ini bertujuan untuk memberikan penyuluhan dan pelatihan pembuatan gel handsanitizer dari ekstrak kemangi. Metode yg digunakan pada pengabdian ini adalah model ceramah dan demonstrasi praktik pemanfaatan daun kemangi sebagai bahan gel handsanitizer. Pendampingan kegiatan ini agar masyarakat mampu mengolah dan memanfaatkan daun kemangi sebagai sebuah produk gel handsanitizer. Selain itu, hasil produk yang dihasilkan dapat dipergunakan sehari-hari untuk membersihakan tangan yang sehari-hari masyarakat beraktivitas di sawah dan peternak.
\end{abstract}

Kata kunci: daun kemangi, antiseptik, gel handsanitizer

\begin{abstract}
The hand is a limb that is often contaminated by microbes. One way to eliminate microbes in the hands is by washing hands using soap. In addition to using soap, hand washing can also use a handsanitizer. One of the plants that can be used as a handsanitizer is basil leaves. Basil extract contains compounds that act as antibacterial namely tannins, flavonoids and essential oils. This activity aims to provide counseling and training to make a handsanitizer gel from basil extract. The method used in this service is a model of lectures and demonstrations of the practice of using basil leaves as a handsanitizer gel. Assistance of this activity is so that the community is able to process and utilize basil leaves as a gel handsanitizer product. In addition, the products produced can be used daily to clean the hands of people who are active every day in the fields and ranchers.
\end{abstract}

Keywords: basil leavef, antiseptic, handsanitizer gel

\section{PENDAHULUAN}

Salah satu tanaman yang mengandung satu atau lebih bahan aktif yang dapat digunakan sebagai obat herbal adalah ialah herbal Kemangi. Kemangi merupakan tanaman yang umum bagi masyarakat yang sangat mudah dijumpai dan dapat tumbuh dimana saja. Umumnya masyarakat Indonesia memanfaatkan daun tanaman Kemangi untuk dikonsumsi. Belum ada pemanfaatan secara maksimal dari daun tanaman Kemangi oleh masyarakat, sedangkan bila dikelola secara baik tanaman ini memiliki potensi yang baik untuk meningkatkan derajat kesehatan serta meningkan ekonomi masyarakat.

Tanaman ini merupakan salah satu tanaman obat tradisional yang terkenal memiliki banyak manfaat. Aktifitas biologi yang sudah diteliti dari ekstrak daun Kemangi sebagai penyegar mulut, antidepresan, antipiretik, antidiabetik, antihiperglikemik juga dilaporkan mempunyai efek aktivitas antibakteri. Kandungan senyawa yang berperan sebagai antibakteri yaitu tanin, flavonoid dan minyak atsiri. Ekstrak daun Kemangi (Ocimum sanctum) sebagai antibakteri memiliki kadar hampir minimum (KHM) dan kadar bunuh minimum (KBM) terhadap Staphylococcus aureus pada konsentrasi sebesar $16,33 \%$ dan $50 \%$ (Angelina et al., 2015). Tanaman kemangi juga dapat digunakan dalam pengebotan tradisional dan telah diketahui kandungan bioaktifnya sebagai insektisida, nematisida, fungisida dan antimikroba. Aroma minyak atsiri 
yang digunakan dalam parfum, sediaan farmasi dan bahan tambahan makanan (Simon, J.E., J.Quinn., 1990).

Berdasarkan penelitian-penelitian yang dilakukan, daun Kemangi memiliki aktivitas antibakteri, sehingga peneliti ingin mengembangkan dan memformulasikan sediaan farmasi dalam bentuk gel antiseptik. Gel dipilih karena tidak mengandung minyak dan memiliki formulasi hidrogel sehingga tidak membuat kulit menjadi terlalu kering. Beberapa keuntugan sediaan gel yaitu penyebarannya baik pada kulit, kemudahan pencucian, tidak menyebabkan lengket dikuliti dan pelepasan obatnya (Voight, 1994). Sediaan gel merupakan sediaan yang banyak memiliki kelebihan bila dibandingkan dengan sediaan topikal lainnya. Gel terasa ringan bila diaplikasikan pada kulit sehingga meningkatkan kenyamana pengguna. Gel memiliki sifat yang lunak, lembut, mudah dioleskan dan tidak meninggalkan lapisan berminyak pada permukaan kulit (Jones, 2003).

Sehingga penting untuk menumbuhkan kreatifitas masyarakat dalam pemanfaatan tanaman yang memiliki potensi nilai ekonomi untuk meningkatkan ekonomi dan kesejahteraan masyarakat dalam bentuk pelatihan-pelatihan pembuatan produk gel antiseptik khususnya dilakukan di Desa Batujai, Kecamatan Praya Barat Kabupaten Lombok Tengah.

\section{METODE}

Pengabdian masyarakat ini dilaksanakan pada hari Ahad 15 Desember 2019, di Musholla Lakah, Desa Batujai.

Metode yang digunakan selama kegiatan ada dua yang pertama untuk Sarasehan dalam bentuk penyampaian materi menggunakan metode ceramah dan diskusi dengan masyarakat sebgai peserta, dimana Penjelasan yang disampaikan meliputi cara membersihkan tangan dengan baik, bagaimana bentuk secara visual tangan yang kotor dibandingkan dengan tangan yang bersih, serta waktu tangan dibersihkan. dan yang kedua pelatihan membat sabun cuci tangan ANTIS secara bersamaan dengan peserta pengabdian, 2 atau 3 peserta ikut membantu.

\section{HASIL DAN PEMBAHASAN Kegiatan Penyuluhan}

Peserta kegiatan

pelatihan pemanfaatan daun kemangi (Ocinum sanctum) sebagai produk antiseptik untuk preventif penyakit di Dusun Lakah, Desa Batujai Kabupaten Lombok Tengah berjumlah \pm 24 orang peserta bersama tim dosen dan mahasiswa Fakultas IImu Kesehatan UMMat.
Pengabdian ini dilaksanakan pada tanggal 15 Desember 2019 yang di awali dengan memperkenalkan diri dan maksud dan tujuan dari acara pengabdian serta dilanjutkan dengan mempersentasikan materi tentang pemanfaatan daun kemangi (Ocinum sanctum) sebagai produk antiseptik untuk preventif penyakit di masyarakat.

\section{Persentasi Materi}

Persentasi

dilakukan untuk menyampaikan informasi secara umum tentang cara membersihkan tangan, pentingnya kebersihan tangan dan penyakit-penyakit yang ditimbulkan jika kebersihan tangan tidak dijaga dengan baik. World Health Organization (WHO) mengungkapkan bahwa ratusan juta orang setiap tahunnya terjangkit infeksi nosokomial ketika berobat atau berkunjung ke rumah sakit. Infeksi ini adalah yang bisa kita dapati setiap kali kita ke rumah sakit. Infeksi bisa kita dapatkan karena kita menyentuh pasien atau peralatan rumah sakit tanpa mencuci tangan setelahnya. Selain infeksi nosokomial, kita juga bisa mengalami infeksi akibat tertular bakteri atau virus ketika bersentuhan dengan orang lain. Sehingga kebersihan tangan harus selalu menjadi prioritas demi kesehatan kita.

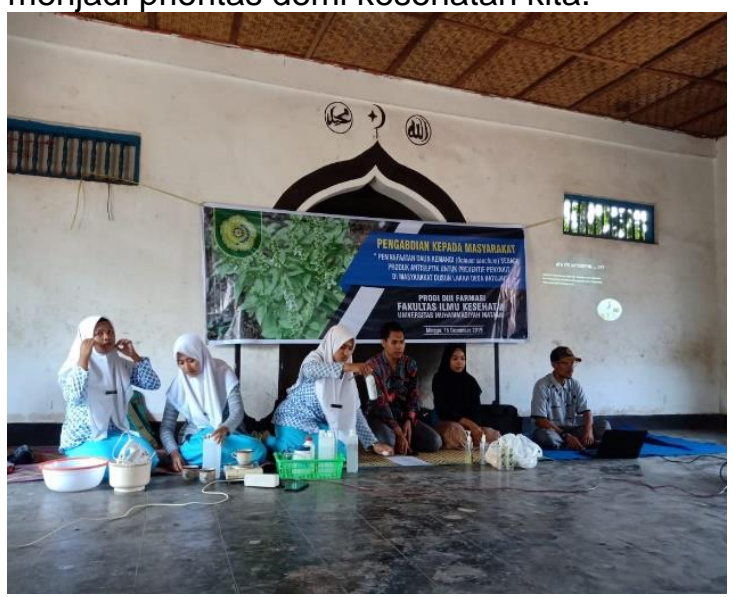

Gambar 1. Persentasi tentang Kebersihan Tangan

Penjelasan yang disampaikan (Gambar 1) meliputi cara membersihkan tangan dengan baik, bagaimana bentuk secara visual tangan yang kotor dibandingkan dengan tangan yang bersih, serta waktu tangan dibersihkan.

Penjelasan yang disampaikan meliputi cara membersihkan tangan dengan baik, bagaimana bentuk secara visual tangan yang kotor dibandingkan dengan tangan yang bersih, serta waktu tangan dibersihkan.

\section{Pelatihan Pembuatan Antis Daun Kemangi} Pelatihan pembuatan sediaan Antiseptik dari daun kemangi di Dusun Lakah dihadiri oleh kalangan muda dan orang tua 
(Gambar 3). Masyarakat Dusun Lakah sangat antusias dalam program ini karena masyarakat selama ini tidak pernah menghiraukan kebersihan dan pentingnya kita menjaga kebersihan tangan dan antusiasnya masyarakat terhadap program pengabdian kepada masyarakat disebabkan oleh hasil dari program ini bisa di nikmati secara langsung yaitu produk ANTIS serta masyarakat selama ini hanya membersihkan tangan denga air biasa. Proses pembuatan produk dapat dilihat pada gambar 2.

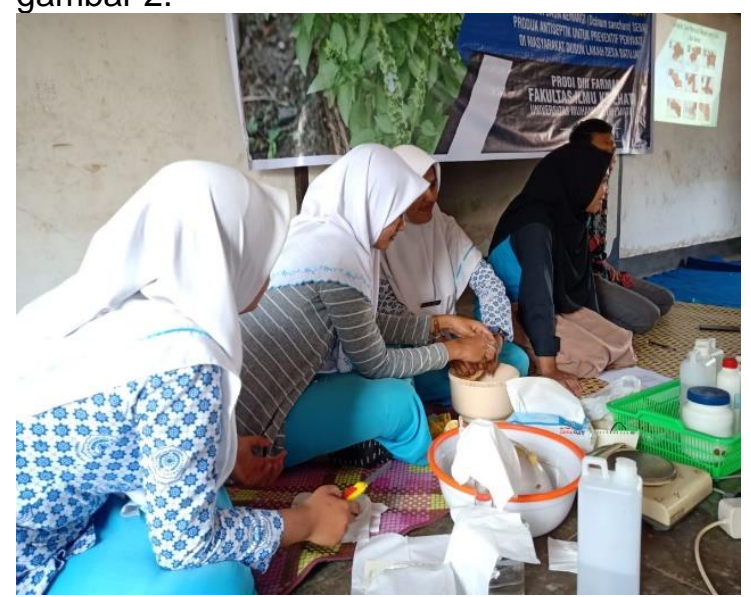

Gambar 2. Proses pembuatan produk ANTIS

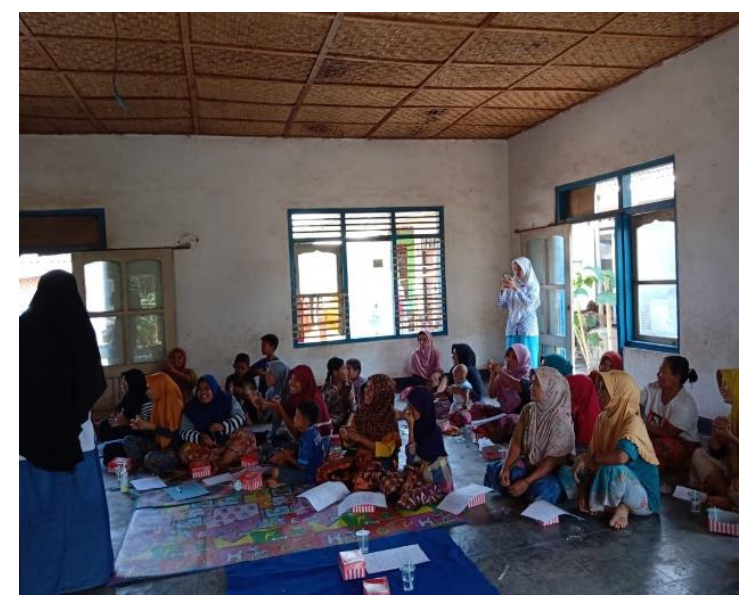

Gambar 3. Pembagian Lembar pembuatan sediaan ANTIS dari daun kemangi

Masyarakat Dusun Lakah menyampaikan bebearapa pertanyaan yaitu, " dimana kita bisa dapatkan bahan-bahan komposisi pembuatan sediaan ANTIS selain daun kemangi dan Lemon, dan pertanyaan selanjutnya yaitu Jika mau membuat sekala besar bagaimana perhitungan dari setiap bahan. Beberapa pertanyaan ini menandakan bahwa masyarakat sangat antusias sekali dalam acara ini, bahkan masyarakat maju kedepan untuk bisa melihat secara langsung cara pembuatan sediaan ANTIS. Pesan dan kesan kepada pihak yang pelaksana program pengabdian kepada masyarakat. Selama ini tidak pernah dilakukan

program pengabdian masyarakat yang dilakukan oleh perguruan tinggi yang terletak di pulau Lombok, sehingga masyarakat Dusun Lakah Desa Batujai sangat antusias sekali.

Pengabdian ini di akhiri dengan pembagian produk hasil pembuatan sediaan ANTIS ke masyarakat dan sesi foto bersama yang ditunjukan pada gambar 4 dibawah ini.

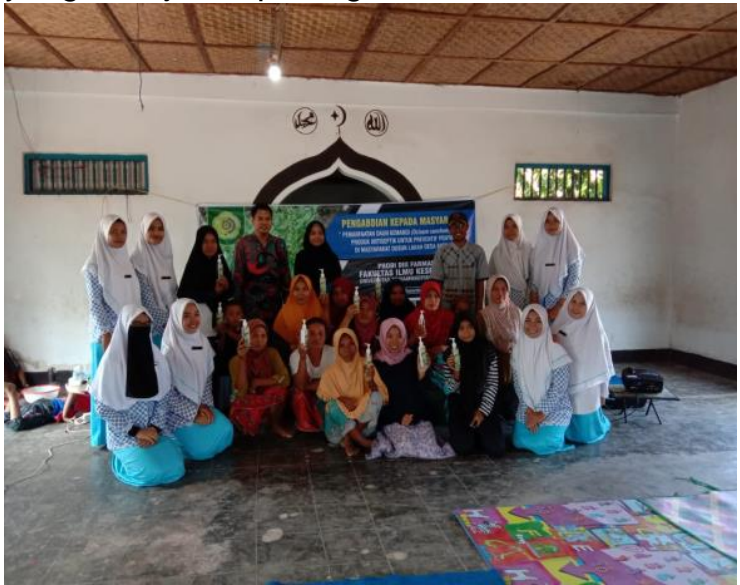

Gambar 4. Pembagian produk ANTIS

\section{SIMPULAN DAN SARAN Simpulan}

Pengabdian tentang pelatihan pembuatan dan Pemanfaatan Daun Kemangi (Ocinum sanctum) Sebagai Produk Antiseptik Untuk Preventif Penyakit Di Masyarakat Dusun Lakah Desa Batujai berjumlah \pm 24 orang. Telah dihasilkan diskusi interaktif antara masyarakat dan narasumber dalam menyampaikan materi. Proses pembuatan sediaan ANTIS dengan melibatkan beberapa masyarakat langsung dalam pembuatan dan disertai beberapa pertanyaan dalam proses pembuatan sediaan ANTIS

\section{Saran}

Saran untuk kampus yang ada di pulau Lombok agar bisa memberikan pelatihan ini secara terus menerus dengan pelatihan yang bervariatif dengan bahan-bahan yang sederhana, dan dpat memberikan pelatihan sejenisnya dengan sekala masyarakat yang luas di Desa Batujai, kemudian membuat kerjasama (MoU) pihak kampus dengan Desa Batujai.

\section{DAFTAR RUJUKAN}

Agusta, A. (2000). Minyak Atsiri Tumbuhan Tropika Indonesia. ITB Press.

Angelina, M., Turnip, M., \& Khotimah, S. (2015). Uji Aktivitas Antibakteri Ekstrak Etanol Daun Kemangi (Ocimum sanctum L.) terhadap Pertumbuhan Bakteri Escherichia coli dan Staphylococcus aureus. Jurnal Protobiont.

Benjamin, D. . (2010). Introduction to hand 
sanitizer.

http://www.antimicrobialtestlaboratorie s.com/information_about_hand_a nitizer.html

CDC. (2009). Hand Sanitizer Ingredients. http://www.hand-sanitizerdispenserreview.com/hand-sanitizeringrediants.httm

Desiyanto, F. A., \& Djannah, S. N. (2013). EFEKTIVITAS MENCUCI TANGAN MENGGUNAKAN CAIRAN PEMBERSIH TANGAN ANTISEPTIK (HAND SANITIZER) TERHADAP JUMLAH ANGKA KUMAN. Jurnal Kesehatan Masyarakat (Journal of Public Health). https://doi.org/10.12928/kesmas.v7i2.1 041

Ghfiari, T. I. (2010). Perancangan Kampanye Cuci Tangan Pakai Sabun Untuk Cegah Penyakit 2010. Digital library Perpustakaan Pusat Unikom Knowledge Center.

Ibrahim, A. dan O. (2013). Bacteriological analysis and hygiene level of food outlets within polytechnic. RR-JMB.

Jones, M. (2003). Dermatological Effect from Years in the Sun; Compounding Oportunities. International Journal of Pharmaceutical Compounding, 10(5), 336-342.

Ma'mun dan Suhirman, S. (2010). Karakteristik Minyak Atsiri Potensial. Jurnal Balai Penelitian Tanaman Obat Dan Aromatik, 110-121.

Masyarakat, J. K., Maylia, N., \& Cahyani, E. (2014). Daun Kemangi (Ocinum Cannum) Sebagai Alternatif Pembuatan Handsanitizier Basil Leaves (Ocinum Cannum) As an Alternative of Handsanitizier. Kemas.

Notoatmodjo, S. (2010). Metodologi Penelitian Kesehatan. Revisi. Rineka Cipta.

RI, K. (2003). Keputusan Menteri Kesehatan Republik Indonesia Nomor 942/Menkes/SK/VII/2003 Tentang Pedoman Persyaratan Hygiene Sanitasi Makanan Jajanan Menteri (p. pp 1-21). Menteri Kesehatan Republik Indonesia.

RI, K. K. (2014). Perilaku Mencuci Tangan Pakai Sabun di Indonesia.

Simon, J.E., J.Quinn., dan M. R. G. (1990). Basil : A Source of essensial oil. Timber Press.

Voight, R. (1994). Buku Pengantar Teknologi Farmasi. Yogyakarta, Universitas Gadjah Mada Press. 